\author{
S. F. Panov \\ Doctor of Technical Sciences, Associate Professor \\ Associate Professor at the Department of Foreign Philology \\ V. I. Vernadsky Taurida National University
}

\title{
FEATURES OF PROFESSIONAL TRANSFER OF SCIENTIFIC AND TECHNICAL INFORMATION USING LINGUISTIC AND SPECIALIZED KNOWLEDGE
}

The article discusses the features of the translation of scientific and technical texts, which are becoming more and more popular and relevant in connection with the accelerating scientific and technical progress of the modern world, analyze the requirements for translators in terms of quality and equivalence of the translation and the original, consider the importance of disseminating the translation of information as a way of sharing in the global community. A study of the specifics of technical translation, the adequacy of the interpreted material, in compliance with the linguistic and technological features of the subject of the translation. The modern process of translating scientific and technical information is a kind of linguistic activity aimed at the most complete recreation in another language of the content and form of a text in a foreign language. For the professional translation of scientific and technical literature, the most important is the adequate transfer of text material and errors are associated with subsequent difficulties in working with the description and maintenance of equipment. The accuracy and adequacy of the translation of the entire text as a whole, as well as its individual parts, determines the quality of the scientific and technical translation. For the correct and complete translation of scientific and technical information, first of all, it is necessary to correctly understand and translate related semantic groups of words, scientific and technical terms. When assessing the quality of a translation, one must take into account not only how correctly all sentences, paragraphs, the text as a whole are translated, but also how much this corresponds to exact general and particular solutions to translation problems. As a result of the study, the relationship of the translation of scientific and technical literature, observing the accuracy, rigor and consistency in the presentation of the material with linguistic and regional and semantic differences in the translation of the same term in different countries of the world, as well as the need for a full understanding by the technical translator of the meaning of the text translated by him, is examined.

The practical significance of the article lies in the efficient use of engineering, digitalization in the process of translator work, linguistic and specialized knowledge, terminology and features of scientific and technical documentation.

Key words: scientific and technical translation, text, equivalence, requirement, scientific style, vocabulary, stylistic feature, language, term, specificity, adequacy, subject, translation quality.

Formulation of the problem. Of all the significant problems of modern translation, an important role is played by the development of such an industry as the translation of scientific and technical texts, which is associated with rapid scientific and technological progress. This type of translation activity is becoming increasingly necessary for new inventions and discoveries. Translation of information from different languages is always fraught with many difficulties for the translator. In this case, all the subtleties of a foreign language should be taken into account. The task of a technical translator is to determine the style and nature of the language of the article, to convey all the subtleties of the source material of the translation without distorting information from the source.

One of the most difficult types of translation is the scientific and technical translation, since an adequate translation of the material into another language requires not only linguistic, but also technical knowledge.

Analysis of the remaining issues Starting in the eighties, a new profession appeared that was associated with scientific and technical translations of information: "highly specialized translator" or "technical translator". A technical translator must not only be fluent in the language into which he is translating, but also possess knowledge of the direction of the translated subject. Today, more and more specialists with technical education receive a second education in the field of translation

Germany over the past decades, about ten new higher education institutions have been founded, which train specialists in the field of "special translation" [1].

Analysis of recent research and publications. Researchers in the field of technical translation were scientists L. Barkhudarov, Yu. Zhukova, I. Kvasyuk, A. Schweitzer, V. Komissarov, L. Latyshev M. Morozov, A. Fedorov and others $[2 ; 3 ; 4 ; 5 ; 6]$. The works on the creation of translation tools for scientific and technical texts are devoted to the works of I. Alekseeva, E. Komissarov and others [7; 8]. Common problems of translator training were considered in the works by 
Ukrainian and foreign scholars T. Kiyak, I. Korunets, N. Vasilishina, J. Albrecht, H.G. Hönig, P.A. Schmitt $[9 ; 10 ; 11 ; 12 ; 13 ; 14]$.

A technical translation is a translation of texts of a technical or scientific subject, documents of varying complexity and specialization, various reference books, terminology dictionaries, certificates of conformity for products, agreements on collaboration, instructions for use and operation, engineering calculations and plans, scientific and technical articles, technical Conclusions, business contracts and other commercial technical proposals. Translation cannot be free retelling while maintaining the meaning of the text being translated. It should not contain any personal, emotional statements and subjective opinions.

Vidilennya nevirishenikh earlier A distinctive feature of the translation of scientific and technical texts is the obligatory knowledge of a technical translator of all scientific and technical terms relating to a specific subject of the technical field of translation. He must understand not only the meaning of the translated terms, words, combinations, but also take into account all the nuances of their use in one way or another. In this case, it is necessary to understand not only the issues of linguistics, but also in engineering, technical disciplines. When translating scientific and technical literature, the style of the original document should always be maintained.

It always has a clear and concise character, a rigorous exposition of technical terminology, clarity and logic of the sequence of actions, uniqueness and concreteness in explaining all phenomena. A slight mistake in translating the technical instruction manual for the equipment may interfere with a successful start-up or lead to improper use of this equipment or an accident. $A$ translator engaged in technical translation must be fluent in both his native and foreign languages, be well versed in technical terminology, engineering inherent in a particular field of activity, be able to work with information flows.

The aim of research. The aim of the study is to consider the features of the translation of scientific and technical texts, which are becoming more and more popular and relevant in connection with the accelerating scientific and technical progress of the modern world, to analyze the requirements for the quality and equivalence of the translation (the original), to consider the significance of publishing in the open press a translation of scientific information as a way to exchange scientific achievements in the global community.

Presentation of the main research material. Every professional translator of scientific and technical literature should have at hand a whole arsenal of auxiliary tools. It includes: scientific, technical and reference literature of various thematic areas, specialized and linguistic dictionaries that will help the translator to avoid inaccuracies and stylistic errors in both languages. Technical translation involves not only translating words from one language to another, but also applying a whole range of skills and knowledge, both linguistic and highly specialized in nature.

From specialists engaged in scientific and technical translation, in addition to linguistic education, certain knowledge in the field of technology is also required. All scientific and technical literature is characterized by the presence of special terminology. A correct technical translation requires a complete understanding by the translator of the meaning of the text, because if he does not understand it, he does not have an idea of how a particular unit or assembly, the description of which he translates, functions, the translator will not be able to reliably and correctly translate this text.

The complexity of scientific and technical translation lies in the fact that many words are polysemantic, and their meaning in different languages often does not coincide, and without knowledge of the subject of translation it is impossible to choose the correct version correctly. Translators are required to have knowledge not only of the theory of the subject of translation, but also practical skills, experience, and the ability to navigate well among the types of technical translation, including oral technical translation, heading translation, annotation translation, abstract and full translation. The most difficult is simultaneous interpretation, as the translator does not have the opportunity to turn to dictionaries and encyclopedias during the translation process.

As for technical terms, these are words or phrases that accurately define the subject, phenomenon or concept of science. The term is based on a scientifically constructed definition. By definition, M.M. Glushko "a term is a word or phrase for expressing concepts and designation of objects, possessing, due to the presence of a strict and accurate definition, clear semantic boundaries and therefore uniquely within the framework of the corresponding classification system" [15].

The complex relationship between the words of everyday language and scientific terms makes it difficult to identify the terminology of individual branches of scientific and technical literature. In this regard, A.D. Schweizer proposes to exclude everyday words from the list of terms if they do not carry a specific burden in the language of technical literature. The terms can be used as words used almost exclusively within the framework of a technical text, as well as special meanings of popular words. For example, lexical units like coercivity(коэрцитивность), keraumophone (керамофон), klystron (клистрон), microsyn (микросин) and others used in electronic texts [16].

At the same time, in these texts, words such as dead (отключенный), ripple (пульсация), rope (трос) and others that have well-known common meanings can also act as terms. 
In terms of terms, we have the most concentrated and economical definition of a technical idea or material object. For example, the term "water" is the scientific definition of a chemical compound, the molecule of which consists of two hydrogen atoms and one oxygen atom. Terms should provide an accurate and clear indication of real objects and phenomena, establish an unambiguous understanding by experts of the transmitted information. Therefore, this type of words has special requirements.

An excellent description of the terminology can be found in the book by Ya.I. Retsker [17, p. 18-28].

Consider the grammatical features of technical English language. The appearance of the English word cannot determine what part of speech it is. One and the same word can be a noun, a verb, or an adjective. Compare:

clock face - цифрерблат and

face the wall - облицьовувати стіну;

horse power - кінська сила;

to power - забезпечити двигуном, механізувати;

doctor's car - автомобіль доктора and

to doctor the car - провести ремонт автомобіля.

And the function of a word in a sentence in English can be determined by the place it occupies. Compare:

box switch - закритий вимикач;

and switch box - розподільна коробка;

big traffic road - велике шосе;

and big road traffic - великий дорожній рух;

motor oil - автотракторне масло;

and oil motor - нафотовий двигун.

Literal translation is permissible and used when for most English words the sentence has equivalents in the native language and when the structure of the sentence is fully consistent in the native language, for example: We all know that without alternating current radio-communication is impossible. $\mathrm{Mu}$ всі знаємо, що без змінного струму радіозв'язок неможливий.

Unlike the language of fiction, which allows for long reasoning and repetition, the technical text is saturated with actual content; therefore, it has a high proportion of aborts with non-personal verb forms and passive constructions. A d. from motor being installed, the city p. m. could be controlled automatically. Оскільки було встановлено двигун постійного струму, регулювання числа оборотів можна було здійснити автоматично.

Due to the rapid development of technology, new terms (neologisms) constantly appear in the scientific language, which even the most recent dictionary does not have time to fix. These neologisms often present great difficulties for technical translation.
Consider examples of translation of technical literature from German. Here there are grammatical phenomena inherent only to him; the language of technical German literature differs significantly from the literary and colloquial language. It is complicated by the presence of detailed complex sentences with infinitive turns, widespread definitions and introductory constructions. Das Molekül befindet sich in ständiger Bewegung. Молекула знаходиться в постійному русі. Zu den wichtigsten Werkzeugen für die Metallbearbeitung gehört die Feile. До найважливіших інструментів для обробки металу належить напилок.

Example of translation analysis of a complex sentence: Aber es gibt Dieselmotoren, die mit Glühkerzen ausgestattet sind, um das Zünden bei kaltem Motor $\mathrm{zu}$ erleichtern. Але $\epsilon$ дизельні мотори, котрі забезпечені накальними свічками, аби полегшити запалювання холодного двигуна.

A.L. Pumlyansky writes that in the scientific or technical literature the author focuses on concrete facts that need to be described and explained. Thus, the author's personality is pushed to the background, and the names of objects and processes are put in the first place and, according to the solid word order inherent in the English language, become subject [18]. As a rule, in the scientific and technical literature, the presentation is not from the first, but from the third person and often impersonal and indefinite-personal constructions of the type are used: it has been found expedient, it is necessary, it is important.

Conclusions and prospects for further researches of directions. Based on the above, we can conclude that the translation of a foreign text is always fraught with a lot of difficulties that get in the way of the translator. The prospects for further research in this direction is the fact that a professional translator must take into account all the subtleties of a foreign language, a language of technical literature, because a high-quality translation is not a simple set of words in a sentence, it has its own style and syllable. An adequate interpretation of scientific and technical material requires not only linguistic, but also technical knowledge [19].

The translator must reliably convey the information, translating the text from the mother tongue into a foreign language or vice versa, maintain the style of the document, give a logical interpretation, taking into account all the specifics of the terminology. D.V. Ranny said that in the process of translating the structure of the language of scientific and technical literature, logic should govern, and clarity should govern its individual elements. The words chosen should be simple and commonplace enough to attract the reader's attention and provide him with an understanding of the meaning [20, p. 75]. 


\section{Список використаної літератури:}

1. www.litera.in.ua $\bullet 54 \mathrm{~KB}$

2. Бархударов Л.С., Жукова Ю.И., Квасюк И.В., Швейцер А.Д. Пособие по переводу технической литературы (английский язык). Москва : Изд. «Высш. шк.», 1967. 284 с.

3. Комиссаров В.Н. Современное переводоведение. Москва : ЭТС, 1999. 187 с.

4. Л.К. Латышев, Провоторов В.И. Структура и содержание подготовки переводчиков в языковом вузе : учебно-методическое пособие. Москва : НВИ-ТЕЗАУРУС, 2001. 136 с.

5. Морозов М.М. Пособие по переводу. Москва : Изд литературы на иностранных язиках 1956. $146 \mathrm{c}$.

6. Федоров А.В. Основы общей теории перевода. Москва : Высшая школа, 1983. 303 с.

7. Алексеева И.С. Профессиональный тренинг переводчика : учебное пособие по устному и письменному переводу для переводчиков и преподавателей. Санкт-Петербург : Издательство «Союз», 2003. 288 с.

8. Комиссаров В.Н. Теория перевода (лингвистические аспекты) : учеб.для ин-тов и фак. иностр. яз. Москва : Высш. шк., 1990. 253 с.

9. Кияк Т.Р. Теорія та практика перекладу (німецька мова) : підручник для студентів вищих навчальних закладів. / Т.Р. Кияк, О.Д. Огуй, А.М. Науменко. Вінниця : Нова книга, 2006. $592 \mathrm{c}$.

10.Корунець І.В. Вступ до перекладознавства : підручник. Вінниця : Нова Книга, 2008. 512 с.
11. Василишина Н.М. Формування професійно-комунікативної компетентності майбутніх фрахівців з міжнародних відносин у процесі вивчення фахових дисциплін : дис. ... канд. пед. наук: 13.00.04 / Василишина Наталія .Максимівна. ; НАУ. Київ, 2014. 20 с.

12.Albrecht J., Baum R. Fachsprache und Terminologie in Geschichte und Gegenwart . Tübingen (Narr) 1992.

13. Hönig,Hans G. Konstruktives Übersetzen / Hans G. Hönig. Tübingen : Stauffenburg-Verl., 1995. $196 \mathrm{~s}$.

14.Schmitt P.A. Fachtexte für die ÜbersetzerAusbildung: Probleme und Methoden der Textauswahl. In: Ehnert r. Schleyer W. (Hgg.) : Übersetzen im Fremdsprachenunterricht. Beiträge zur Übersetzungswissenschaft- Annäherung an eine Übersetzungsdidaktik. Regensburg (AkDaF) 1987, S. 111-151.

15.Глушко М.М. Функциональный стиль общественного языка и методы его исследования. Москва : Наука, 1974. 215 с.

16.Швейцер А.Д. Перевод и лингвистика. Москва : Воениздат, 1973. 280 с.

17.Рецкер Я.И. Методика технического перевода. Москва : Дрофа, 2007. С. 14-20.

18.Пумлянский А.Л. Введение в практику перевода научной и технической литературы на английский язык. Москва : Наука, 1965. 304 с.

19. Hubka V., Theorie der Maschinensysteme, Berlin, Springer, 1974

20.Ranni D.W. The Elements of Style. (An Introduction to Literary Criticism). London, 1951.

\section{Панов С. Ф. Особливості професійного перекладу науково-технічної інформації} з використанням лінгвістичних і спеціалізованих знань

У статті розалянуто особливості перекладу науково-технічних текстів, які стають все більш затребуваними і актуальними в зв'язку з прискореним науково-технічним прогресом сучасного світу. Проаналізовані вимоги, що пред’являються до перекладачів за якістю і еквівалентністю перекладу та оригіналу. Розглянуті значимість поширення перекладу інформації як способу обміну в світовому співтоваристві. Проведено дослідження специфріки технічного перекладу, адекватності інтерпретованого матеріалу з дотриманням лінгвістичних і технологічних особливостей предмета перекладу.

Сучасний процес перекладу науково-технічної інфоормації є своєрідною мовною діяльністю, спрямованою на найбільш повне відтворення змісту і фрорми тексту іноземною мовою.

Для профресійного перекладу науково-технічної літератури найбільш важливим є адекватна передача текстового матеріалу, і помилки пов'язані з подальшими труднощами в роботі з описом і обслуговуванням техніки. Точність і адекватність перекладу всього тексту загалом, а також його окремих частин визначає якість науково-технічного перекладу. Для правильного і повного перекладу науково-технічної інфоормації передусім необхідно правильно зрозуміти і перевести пов'язані між собою смислові групи слів, наукові та технічні терміни.

Під час оцінки якості перекладу треба враховувати не тільки те, наскільки вірно переведені всі пропозиції, абзаци, текст в цілому, але і те, наскільки це відповідає точним загальним і приватним рішенням завдань перекладу. В результаті дослідження розглянуто взаємозв'язок перекладу науково-технічної літератури, яке б точність, строгість і послідовність у викладі наданого матеріалу з лінгвокраїнознавчими і смисловими відмінностями перекладу одного і того ж терміну в різних країнах світу, а також необхідність повного розуміння технічним перекладачем сенсу перекладного їм тексту. Практична значимість статті полягає в ефективності використання інженерії, дигіталізації в процесі роботи перекладача, лінгвістичних і спеціалізованих знань, термінології та особливостей науково-технічної документації.

Ключові слова: науково-технічний переклад, текст, еквівалентність, вимога, науковий стиль, лексика, стилістична риса, мова, термін, специфріка, адекватність, тематика, якість перекладу. 